\title{
IBU OR THE BEAST: Gender Interests in Two Indonesian Women's Organizations ${ }^{1}$
}

\author{
Saskia Wieringa
}

\section{Introduction}

One of the most stimulating attempts to develop a theoretical framework for the analysis of women's organizations is that of Maxine Molyneux, who makes the distinction between organization for practical and strategic gender interests. Part of the attraction of the distinction is that it promises to be a tool in efforts to assess the performance of women's organizations. However, these concepts are widely, and generally uncritically, used in discussions which deal with 'women and development' issues, particularly in relation to women's organizations in the South. I have various analytical and conceptual problems with the concepts of practical and strategic gender interests. In the space of this article, I will not be able to spell these out in detail. Instead I will use the example of two mass organizations of Indonesian women to focus on some of the ambiguities in these concepts.

Molyneux has suggested that it might be useful to differentiate between women's strategic and women's practical gender interests in assessing the 'success' of certain policies regarding women, specifically addressing the performance of the socialist state of Nicaragua. Strategic gender interests she defines as being 'derived from the analysis of women's subordination and from the formulation of an alternative, more satisfactory set of arrangements to those which exist'. Practical gender interests, on the other hand, 'are generally a response to an immediate perceived need and they do not generally entail a strategic goal such as women's emancipation or gender equality' (Molyneux, 1985: 240).

I will address myself here to the conceptualization of the term 'practical gender interests'. I will argue that the critical distinction in 
assessing the performance of, in this case two organizations, lies not so much in the nature of the activities they carry out, or in the issues which their programmes address, but rather in the underlying perspective which determines the way these activities or programmes are shaped. In this discussion I will focus on both the continuities and the dissimilarities in the activities of the two organizations under discussion and in the perspectives from which they work/ed.

The organizations we will deal with are the Gerwani (Indonesian Women's Movement) and the PKK (Family Welfare Guidance). There are wide differences between these two women's mass organizations. Gerwani was the left-wing women's organization in Indonesia which was banned after the coup of 1965. Many thousands of its members were brutally killed in the ensuing campaign to wipe out all traces of the former prominent left organizations, and especially of the PKI, the Indonesian communist party. The army under General Suharto succeeded in exploiting the latent fear of the 'Communist Beast' to portray Gerwani members as morally depraved women. PKK is the present-day mass organization set up by Indonesia's New Order government. Although the government presents it emphatically as a general mass organization dealing with family affairs it is generally seen as a women's organization. Women are supposed to play a prominent role in the family so in practice the PKK is almost entirely directed towards women.

Using Molyneux's terminology, both Gerwani and PKK can be seen to address primarily women's practical gender interests. However, I will show that underlying strategic concerns informed the practice of these organizations in such a way that, although they carry out comparable activities, the effects of their work has fundamentally different implications. I will start with giving some historical background.

\section{Indonesia since 1950}

After a prolonged war of liberation against the Dutch colonial power, Indonesia gained its independence in 1949. Ir Sukarno was the first president. He had actively tried to engage the support of the Indonesian women's movement in the national struggle. And indeed women had come to the fore: they had set up public kitchens, organized medical help for the wounded, and had been active in establishing communications between the various guerrilla groups; some women had also fought in the guerrilla forces. In the new Constitution women were granted the same legal and political rights as men, although the marriage law was not reformed, an issue the women's organizations had been fighting for long before the Second World War.

The unity of the women's organizations achieved during the revolutionary years soon crumbled (Wieringa, 1985). In the face of the coming elections (1955) women started organizing themselves along the various political streams. Apart from this political diversification, 
women's organizations based on religious and ethnic differences came up as well.

From 1950 until 1959 Indonesia knew an unstable system of parliamentary democracy. The elections in 1955 , the first and only really democratic elections in Indonesia so far, did not bring the desired stability. The Communist Party of Indonesia, the PKI, surprisingly gained a strong fourth position in the elections, with 16.3 per cent of the votes. Gradually, the Indonesian political scene became dominated by tensions between the three dominant political groups, the army, the Muslims ${ }^{2}$ and the Communists. President Sukarno's personal charisma was the main mediating factor in preserving a delicate balance. He became increasingly frustrated in his efforts to forge national unity, and in 1957 he created a National Council in which all non-party-affiliated functional groups participated, including the army. In the following years this Council, chaired by Sukarno himself, became the major locus of political power (Feith, 1962; May, 1978; Ricklefs, 1981).

In 1959 Sukarno swept aside parliament and declared the policy of Guided Democracy. In 1960 he launched the Nasakom formula: Nationalist (NAS), religious (A from agama, religion) and Communist (KOM) forces should cooperate to build a stable and prosperous Indonesia. For the first time the Communists were drawn into the government, much to the dislike of the army, which, although officially left out of Nasakom, increasingly began to dominate the political, economic and of course military scene. Sukarno needed both the PKI and the army in his struggle against the conservative forces in society. The PKI because they were able to supply him with the mass support he wanted, and the army because it supported him in his nationalist, military campaigns. Increasingly, Sukarno sought to build national unity through mass military campaigns: the struggle for the liberation of Irian Jaya and the Anti-Malaysia campaign. ${ }^{3}$

Although the attention of the president was turned towards the struggle against imperialism more than towards the construction of domestic socialism, some socialist measures were introduced, such as a land reform in 1960. When little progress was made in the implementation of this law, the left-wing farmers' union, supported by the PKI and Gerwani, started their 'one-sided actions': peasants tried to acquire land by force. Around 1964 this policy led to enormous tensions in the countryside: conservative landholders, many of them belonging to Islamic groups, became antagonized.

In this extremely delicate political situation, with an almost bankrupt economy, on 30 September 1965, a group of middle-ranking army men abducted and killed six conservative generals. They tried to get the support of the PKI and of President Sukarno, but how far they were actually involved in this clumsy putsch remains unclear (Anderson, 1987; Gunawan, 1968; May, 1978; Mortimer, 1974; Törnquist, 1984; Wertheim, 1978 and 1985). There are also indications that the current president, Suharto, was involved, but there is no clear proof of his involvement either (Wertheim, 1985). However, General Suharto 
quickly regained control. He managed to instigate a mass campaign in which the full blame for the coup was laid on the PKI. In the following months the PKI and the country's left-wing mass organizations, including the Gerwani, were completely destroyed. Most reports agree that around half a million people were killed. Tens of thousands were imprisoned, of whom only some two hundred were ever tried.

In 1968, Suharto became the country's new president. The army and the civil services were purged of people with leftist or left nationalist sympathies, a process which is still continuing. The army has gained absolute dominance in political and civilian matters; even the Muslim groups which had assisted the army greatly in the mass murders of left people are left with less power than they had before 1965. All mass organizations including the women's organizations were put under strict government control. PKK is one of the government's instruments to propagate its policies among women.

In comparing Gerwani and PKK I will start by discussing their position in the national political arena. I will then focus on the structure of the organizations, the range of their activities and their ideology.

\section{Position in the national-political arena}

Gerwani grew in a process of nation-building. After the national liberation war Sukarno forged national unity by using a mixture of nationalist and socialist slogans and programmes. Many Gerwani leaders and members had been active in the war and the organization fully supported the struggle for a unified Indonesian republic. Sukarno himself had always insisted on the participation of women in the nationalist struggle (in fact, the subtitle of his book Sarinah is: The Duty of Women in the Struggle for the Indonesian Republic). Later his interest in women's issues dwindled. In 1960 he is quoted as saying: 'We don't need a feminist struggle. That time has passed. It is not the opposite sex that causes the inequalities in society' (Harian Rakyat, 18 May 1960).

Gerwani, however, did find some fault with the male sex and also with the president himself. While the majority of women's organizations was struggling for a marriage law in which polygamy would be prohibited, Sukarno's private life became filled with more and more wives. No more help in the struggle against polygamy could be expected from the 'Supreme Shepherd of the Women's Revolutionary Movement' as he had himself called. Unlike another prominent women's organization, Perwari, ${ }^{4}$ however, Gerwani decided not to attack the president too harshly for this betrayal of the feminist cause which he had supported so heartily. Gerwani leaders suppressed their individually felt frustration about the conduct of Sukarno in the hope of the ultimate rewards of the 'just and prosperous society' which their polygamous president promised them (Wieringa, 1988a).

In justifying this political choice, the space for Gerwani's feminist politics was considerably narrowed down. Sukarno's 'betrayal' of the 


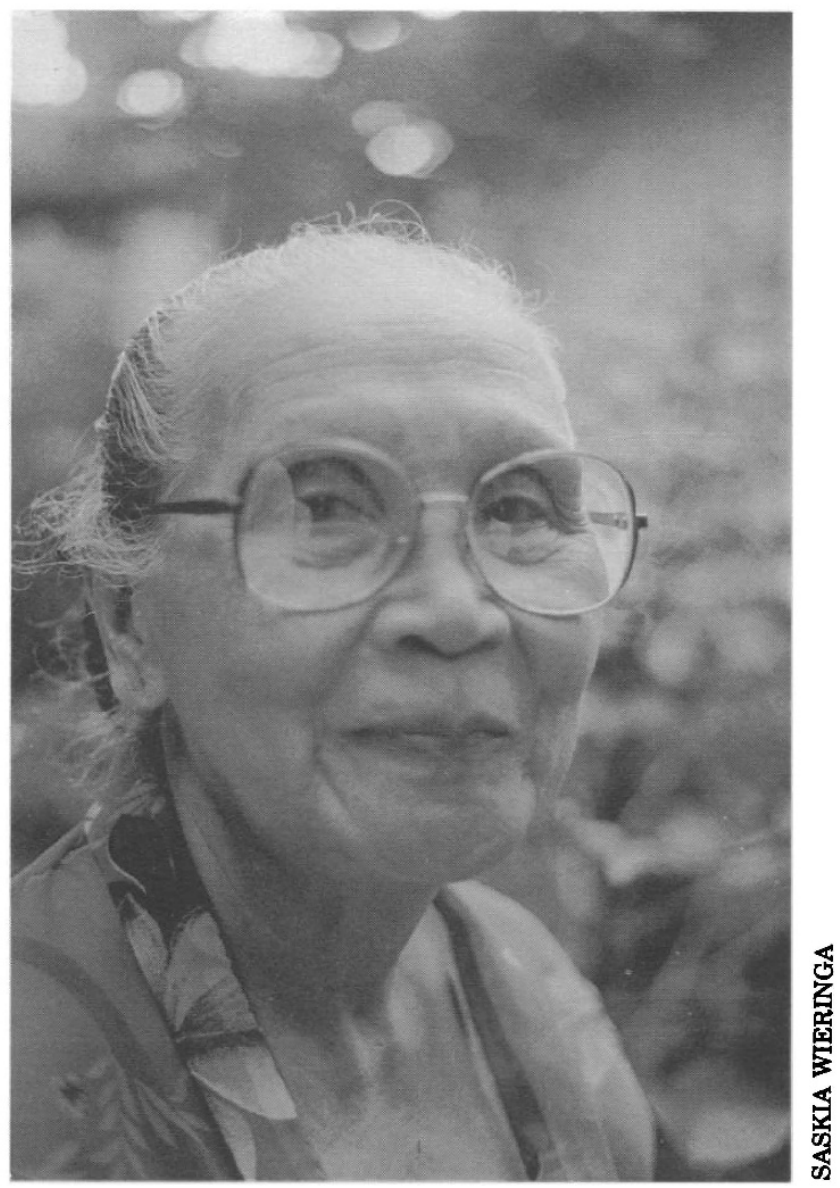

Old time activist in the Nationalist Women's movement. Java.

feminist cause meant a weakening of the 'feminist' wing of Gerwani. Their support of the president meant that the gap with Perwari, formerly an ally, widened. Yet the cooperation with the PKI and Sukarno afforded the Gerwani leadership the opportunity to challenge women's subordinate position in new ways. It gave them a certain legitimacy to make feminist claims to the government. Also, it allowed the women's organization to publicly denounce the idea that women are submissive and docile, and to stress the militancy of Indonesian women. With the support of the PKI, Gerwani tried to convince the government of the urgency of two of its feminist concerns: the demands for a new marriage law and the demand that women should be allowed to be elected as village heads. Thus Gerwani's position, although circumscribed by its ties to the PKI and the desire of the PKI to support Sukarno, nevertheless allowed it to stage various antigovernment demonstrations. The organization supported women workers and 
peasants against landlords and factory owners, and severely criticized the government's economic failures, concentrating on the issue of food prices.

It is difficult to assess how 'successful' Gerwani was in its lobbying. On a practical level their demands were not met. The new marriage law was not passed until 1974; it restricted polygamy but did not abolish it. The struggle to have women accepted as elected village leaders died down quietly; at present hardly anything is heard of it. Likewise their economic demands were not met; on the contrary, the economic decline of the country was disastrous. On an ideological level it is virtually impossible to find out to what measure the consciousness of Gerwani members was raised before 1965. It was most unsafe to refer to one's association with Gerwani after 1965.

The relationship between Gerwani and the PKI, a major actor in the national field, is complex. To an increasing extent, the women's organization supported many policies of the PKI, particularly in the international field. The PKI 'used' Gerwani to mediate its policies to a potential electorate among women. From the end of the fifties, Gerwani members were increasingly mobilized for mass rallies. On the local level, Gerwani members demonstrated against arrests of communist peasant or labour leaders. But Gerwani never supported the PKI automatically. Gerwani leadership frequently disapproved of the PKI line. On the whole, they resented the fact that the PKI leadership did not pay much attention to women's issues. Unlike Lenin and Mao for instance, PKI chairman Aidit rarely paid more than lip service to the 'woman question'. Over all, the PKI saw women's public role essentially as an extension of their domestic tasks. To the PKI the 'woman question' would be solved when the colonial, imperialist and feudal aspects of Indonesian society had been removed. Gerwani was more dubious about this and at any rate they wanted immediate changes. Women's double burden, which the PKI recognized as an issue to be resolved in a vague, distant future, impeded women presently, so Gerwani leaders said, and therefore kindergartens had to be set up and men had to share in the domestic work. For similar reasons they were of the opinion that the struggle for a democratic marriage law should not wait any longer. Male PKI members who wanted to marry a second wife were denounced as antirevolutionary, a strong accusation against a member of a Communist party.

Because PKK consists of the wives of civil servants and members of the armed forces, the link between the present government and the PKK is much more direct. PKK cadres are members of the government party, the Golkar (acronym of Golongan Karya, a collection of functional groupings). The government stimulates a capitalist path of development which is built on internal stability and order. This stability and order in its turn is forged in an incessant campaign against the supposed evils of communism. ${ }^{5}$ Ideologically, therefore, PKK is set up to construct an image of womanhood which is virtually the opposite of the ideal of womanhood Gerwani tried to create. Not militance, but obedience is 
stressed. Women are called upon to sacrifice themselves in the interests of a male-dominated household, which, as the 'smallest unit of society' is ultimately designed to support government politics. The full weight of the state machinery is used to create obedient wives and submissive supporters of the central government. If individual PKK leaders disagree with either the hierarchical line of command or with the content of the programmes they are supposed to carry out, their concerns cannot be translated into open debates and dissent. The only way in which they can show their discontent is by becoming passive. They cannot constructively try to mediate the interests of PKK members to the government if those interests are not parallel to those of the government. Although officially PKK cadres are 'volunteers', in actual practice they are virtually unpaid government servants. They are supposed to serve their government so faithfully that their interests practically converge with government interests.

\section{Structure}

The internal structure of Gerwani and PKK is characterized by both parallels and dissimilarities. Neither Gerwani nor the PKK were autonomous organizations in the sense that many present-day feminist organizations are (Wieringa, 1988b). PKK is the government women's wing, while Gerwani was firmly entrenched in the 'left family', although the organization never became officially affiliated to the PKI.

Another parallel was the mass base of both organizations. Both sought to organize the masses of women but from a different perspective: PKK to subordinate women, Gerwani to make women critical members of society, supporting a leftist political position. Also, both organizations had hierarchical structures. But the hierarchy in each organization operated in different ways. The PKK does not even make an attempt to feign a democratic face. Orders come from above and have to be carried out.

The structure of Gerwani was democratic centralist. This meant that the voices from above were heard more loudly than voices from below. Yet, especially on the various congresses held, common members could and did express their views and communicated their concerns to the leadership. The Gerwani leadership in its turn tried to intervene on behalf of its members on the national scene.

Gerwani's leadership was mainly middle class. This is common among most mass-based organizations operating on national level. The women achieved their leadership positions by their personal capacities, hard work and their interest in study. Although many leaders had more or less close ties with male leaders of the PKI, in no way was their position derived from their husbands. There were quite a few cases in which women had a higher position than their husbands. They were not a homogeneous group of women and had sometimes fierce debates 
among themselves. Historically, a shift in their allegiance can be noted: from the end of the fifties onwards they moved closer to the PKI.

The leaders of the PKK are both upper-class political women and men and middle-class women and men. Although the women do the actual work, their husbands have important functions behind the scene: they are the theorists and 'guides'. The women leaders have all acquired their positions through marriages to top-level men. Thus their leadership is ascribed and is not necessarily related to any personal achievements, or even to an interest in the PKK. This situation often leads to cases of mismanagement, passivity and unconcern. On the other hand, capable women whose husbands are too low in the government hierarchy to 'offer' their wives a high position in the PKK may also become frustrated: their capacities are underutilized, there is no place for their enthusiasm, drive and critical insights in the decision-making process.

As the government structure reaches down to all layers of society and to all corners of the archipelago, PKK cadres are active all over Indonesia. Discontinuity in PKK's activities may occur when leaders have to withdraw because their husbands lose or step down from their influential positions. Within these constraints some women are able to find an outlet for their energies in the PKK and they may even try to make use of the possibilities which PKK offers them to do some meaningful work.

The major concern of PKK leaders is not the question of women's subordination in Indonesian society, but support of the government in power. The structure is centralist, hierarchical and authoritarian. PKK's major objective is to integrate Indonesian families in the development process. Issues like unequal power relations within families are not dealt with. No attention is paid to the voice of the common members of the PKK; only if certain targets are not reached does the PKK leadership try to address the obstacles which they distinguish. In those cases where capable cadres are able to carry out elements of the PKK programme which have a direct relevance to women's daily needs, the daily concerns of the members can be served.

As far as the composition of Gerwani's membership is concerned, until 1954 both members and leaders were mainly recruited from earlier women's organizations, groups which had been active during the war and from left-wing or nationalist parties. Throughout its history the leadership continued to be mainly recruited from these groups but the membership widened up. After 1954 the majority of the new members came from poor urban or peasant backgrounds with no clear organizational history. Also middle and lower-middle-class housewives joined the organization. Members were registered and paid dues. Apart from the reasons listed above to join Gerwani, women were probably largely drawn to the organization because of its social work. Women who dropped their children at the kindergarten were almost automatically registered as Gerwani members. Many women too were attracted to the organization because it offered them practical help and advice when 
they were unilaterally divorced or experienced other problems in their marriages. Others simply joined because members in their families belonged to other progressive mass organizations like the youth organization, the peasant or trade union, or because they wanted to avail themselves of the courses it offered. Gerwani activities on the local level were generally planned on the basis of the direct needs of the women, and after their problems had been discussed extensively.

PKK cadres draw the participants of their activities from roughly the same groups as Gerwani did. However, PKK cadres come to the women of the villages and kampung (neighbourhoods) with preestablished programmes. Women's concerns which do not fall within such programmes will not be taken into account. If members happen to live in an area in which the leaders are active and capable, they may profit from the organization. Provided PKK members do not question the government's wisdom, do not strive to transform the existing order and do not rebel against the ideal of wifehood which is propagated by the organization, they may find something in the organization for them. Members who are enthusiastic about the organization and who are capable and willing to fulfil a more responsible position within PKK cannot become cadres. They can not follow cadre courses, as Gerwani members could; the only way of upward mobility is through the career of their husbands. Thus the PKK programme does not take women's concerns nor women's rights as its starting point; rather women's duties as obedient wives and loyal citizens are stressed. The PKK leadership decides the priorities of the organization in line with government policy.

\section{Range of activities}

The greatest parallels between the two organizations can be found in the range of their activities. Both started from the direct economic needs of the women they work with, but they did so from a completely different perspective.

Gerwani members at the local level carried out manifold activities. They set up crèches, gave literacy classes and cooking and sewing lessons, helped women in their agricultural tasks and encouraged them to engage in non-farming income generating projects. Apart from this they also intervened on behalf of the women in conflicts with landlords or husbands.

Activities to be carried out were determined by meetings of the members themselves. Gerwani cadres acted in those meetings as careful listeners to the needs of the village women. In carrying out the plans made up at those meetings the effectiveness of the cadres was often circumscribed by the insufficient resources available.

PKK members also engage in a multitude of activities. They may, for instance, learn some practical skills, such as sewing or making cookies to sell. The skills taught are usually an extension of their domestic activities. If the PKK engages in small-scale income generating projects, these projects are not geared towards making women 


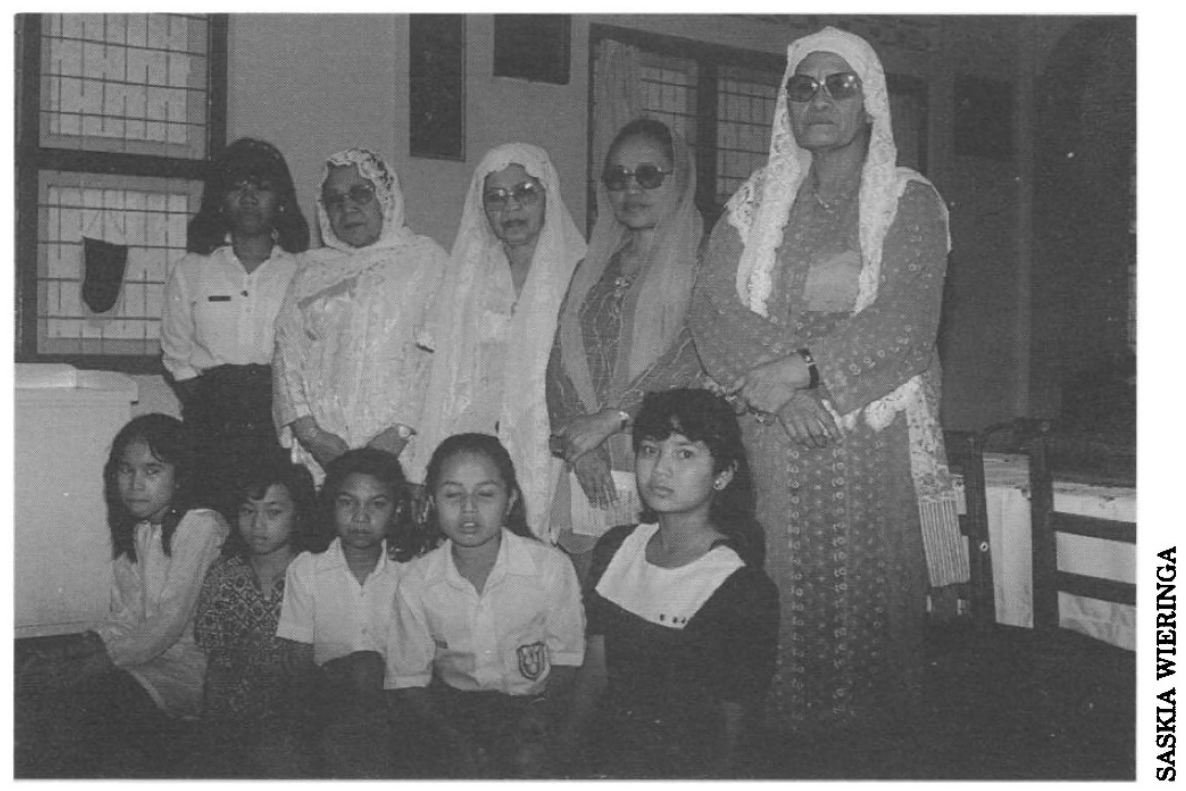

Islamic Women's group with girls from the orphanage they sponsor. Bukittingi, Sumatera.

economically independent, as Gerwani tried to do, but to supplement the 'main' income of the husband. Not all of the activities of the PKK members deserve to be called directly relevant to their daily problems (eg. courses in arranging flowers, and beauty contests.)

The Pancasila ${ }^{6}$ course is the first activity on PKK's list of 10 points. It is obligatory for the whole population, and it is routinely given to those PKK members who have not yet followed one. After that, the cadres are more free to select elements from the programme. However, in actual fact their choices are very much determined by the activities which are carried out through other government agencies (such as the departments of health, education and agriculture) and by the priorities set by the village co-operative, the LKMD (Lembaga Ketahanan Masyarakat Desa, Institute for Village Resilience). The village headman, husband of the chair of the PKK, is the head of this co-operative, which is the official organ through which the government programmes are carried out at the local level.

\section{Ideology}

The greatest difference between the two organizations is to be found in their ideological perspectives. The two organizations have completely different world views. Gerwani fought for a transformation of society, and for women to be active and vocal members of that society. The PKK wants to 'integrate' women into the present right-wing military bureau cratic state (Crouch, 1978), without questioning either the nature of 
that state or indeed the conditions under which women are already 'integrated'.

Each organization has upheld a different ideal of womanhood. Both have propagated 'ibuism', but what kind of $i b u$ s (literally 'mothers') have they proposed? Neither organization sought to challenge women's roles as wife and mother. However, PKK's ibus are obedient and loyal, don't protest, and submit themselves to the authority of husbands and fathers, and ultimately of Bapak Pembangunan (Father of Development), President Suharto, himself. Whereas Gerwani's women were independent and strong; they were not submissive, and they were often stimulated to follow the examples of strong warriorlike women like Srikandi (one of the characters in the wayang, the national shadow puppet theatre). Gerwani women were also actually trained to become guerrilla fighters. Also, Gerwani members were in the forefront of the struggle against sexual violence against women, such as wife-beating and rape. These are not issues that PKK is concerned with.

Because the gap between the popularly held image of Gerwani in present-day Indonesia, as morally depraved human beings, and the ideas Gerwani members themselves had about their own organization differ so vastly, it is interesting to examine Gerwani's ideology somewhat more closely. Due to limits of space, I will not be able to give more than an indication of Gerwani's ideas. Generally its ideology might be characterized as eclectic with a preponderance of socialist ideas. Elements from Indonesian history figured strongly in its teaching. An issue like the introduction of women into waged labour, a Marxist panacea to end women's oppression, did not gain much prominence, essentially because the issue was irrelevant for the lower-class women, who were all earning some income. Gerwani's socialism can be firmly located in the national ideological discourse of its time. Socialist inspiration was also drawn from the achievements of other socialist countries such as China or Russia, for instance in the field of child care or of socializing the household. Regularly articles appeared in both Harian Rakyat (the PKI newspaper) and in Api Kartini (a Gerwani periodical intended for middle-class women) about these issues. A topic which the Gerwani leadership introduced in the national arena was their opposition to the 'moral decadence' which they associated with the products of American imperialism, such as films.

Gerwani also paid attention to more traditional women's issues. Both in Harian Rakyat and in Api Kartini emphasis was put on women's roles as mothers and wives. Recipes, articles on dress-making and child care regularly appeared. Gerwani saw itself as carrying special responsibility for child care, much attention was paid to Children's Day. But whatever emphasis the organization put on women's roles as wives and mothers, Gerwani promoted women's roles as social activists as well. To the great dismay of Islamic and Christian groups, Gerwani members were stimulated to fight for their own rights and to join demonstrations against landlords and factory owners. Sometimes demonstrations against the state were held (as in the anti-price-rise 


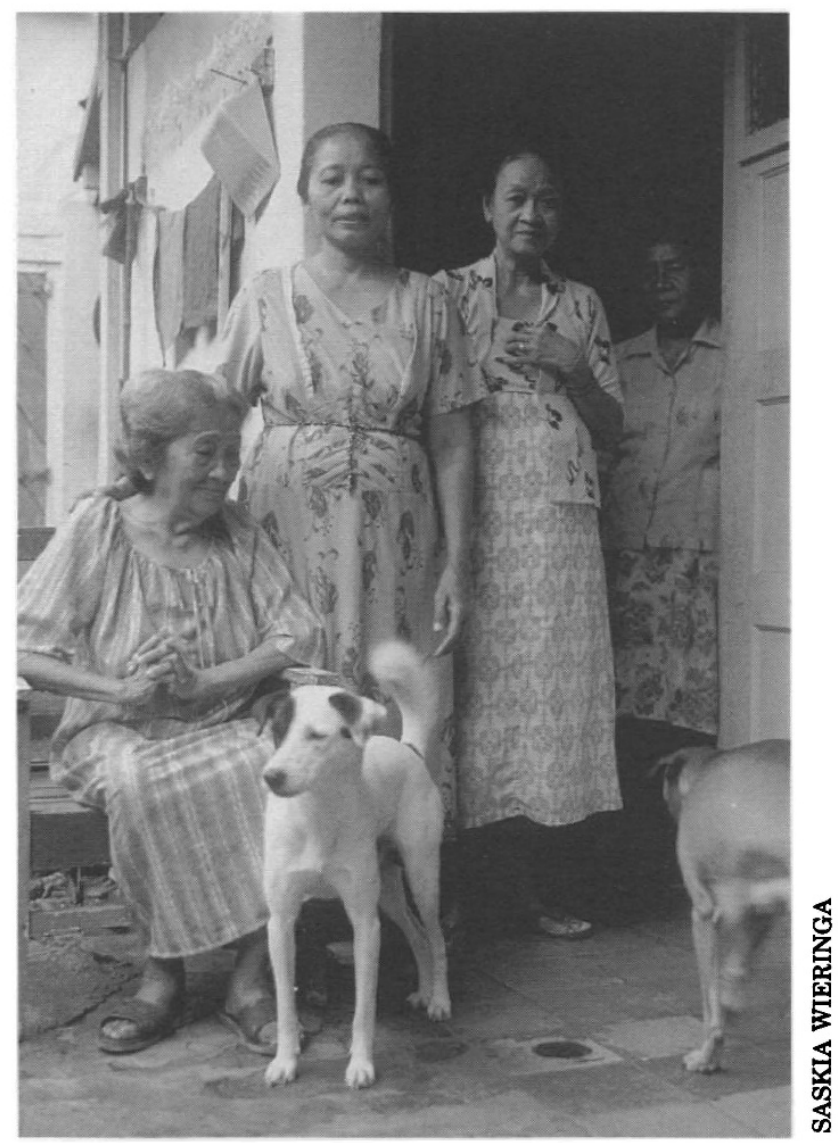

Ibu Salawati Daiud with some of her friends. Jakarta.

demonstrations), at other times women were mobilized to support national policies that the leadership approved of. The keyword which Gerwani consistently used in this respect is gegigihan (militance). The militant role of Gerwani members in Indonesia's 'continuous revolution' is stressed, both in the sense of defending that revolution against its 'imperialist' enemies and in struggles against landlords. High moral standards were set for cadres. Gerwani's chairperson Umi Sardjono listed in 1964 the following characteristics: 'Gerwani works diligently to create cadres who are courageous, capable, possess culture and who possess the following three good character traits: they can work well, they study well and they have good morals' (Sardjono, 1964: 4).

To conclude this section on Gerwani's ideology, it has to be emphasized that, contrary to what was said about Gerwani later, the organization upheld the ideal of women living in morally correct, heterosexual, monogamous families. In this way it did not differ much from the PKK. But there is a difference in the way Gerwani and PKK 
saw the family. Gerwani propagated families which would live according to both national and revolutionary norms. The relationship between wife and husband would be characterized by mutual aid and respect and equality, not by subordination. All members of those families would be involved in progressive organizations, but in their own right, and according to the capacities and energies of each. Also, the women's organization recognized that the double burden which women faced, as well as their marital problems, were not just the consequence of feudalism, but were rooted in the everyday conduct of individual women and men. On the whole women were seen as independent persons, in the social, economic and political field.

PKK conceptualizes families in a different way. A hierarchy between husband and wife is stressed. PKK promotes the Panca Dharma Wanita (Five Duties of Women), which are: to be loyal companions of their husbands, to procreate for the nation, to educate and guide their children, to regulate the household and, lastly, to be a useful member of society. All these tasks preferably are to be carried out in a way which is according to the Kodrat Wanita (Woman's Nature). This Kodrat entails that women are lemah lembut (soft and weak), don't speak out loudly, and certainly not in their own interests, don't push their own interests against those of husbands and fathers, but are instead compliant wives and mothers and dutiful daughters. Women's central role is seen to be located primarily in the family. Contrary to the Indonesian socio-economic reality, where poor women are generally major income earners (Wieringa, 1981), their economic role is largely denied. Women are essentially seen as appendages to their husbands, while it is 'the husband's function to bear responsibility for and protect the family, act as a responsible leader, give examples of good behaviour and earn a living for the family' (Moenadi, 1971: 5).

\section{Concluding remarks}

Coming back to my discussion on the distinction Molyneux made between women's practical and strategic gender interests, I must conclude that both Gerwani and PKK have carried out a similar range of activities based on the immediate perceived needs of women. However, both organizations have worked towards different goals. Politically Gerwani fought for a transformation of society in which women would be active and vocal members, whereas PKK wants to 'integrate' women into the present state. Moreover, there is a vital difference in the way the leaders of both organizations conceptualize womanhood.

Thus both Gerwani and PKK can be said to have engaged themselves mainly with what Molyneux calls 'practical gender interests'. But they have done so in different ways. Gerwani cadres tried to link women's practical, daily concerns to issues of national interest. In cooking lessons issues of landownership and imperialism might be discussed, in the literacy courses the president's book and speeches 
were studied. In this way members were given political education. This form of consciousness-raising received most attention in the years between the 1954 congress and the early sixties. After that period cadres were urged to enlist as many members as possible. With so much emphasis being put on the quantative growth of the organization, consciousness-raising was sometimes neglected.

Such discussions are absent from any cooking demonstration organized by the PKK I have witnessed. Generally the recipes are composed in Jakarta, which may mean that they require ingredients which are not locally available in every island or region. Cooking contests are regularly held in which the emphasis is put not so much on the nutritional value of the various dishes, but rather on the way in which they are presented.

Molyneux asserts that 'these practical gender interests do not in themselves challenge the prevailing forms of gender subordination, but they arise directly out of them.' (Molyneux, 1985: 241) In the light of the discussion presented here this position is not tenable. The major criterion to determine whether a concern with 'practical gender interests' challenges the gender relations in society is not the nature of those interests in themselves. Given their different perspectives on society and womanhood, the effects of PKK's and of Gerwani's concerns with the same type of activities have been quite different. In the case of the PKK the way the organization tackles the daily problems of women only serves to reinforce women's gender subordination by locating women's position firmly in the household under male leadership. Whereas Gerwani, while to a large part concentrating on the same problems, managed to gradually project such a different image of women that it greatly antagonized right-wing groups. So antagonized were they in fact that when grotesque accusations against Gerwani members appeared, ${ }^{7}$ enough people used the excuse to kill Gerwani members in order to 'purge' society.

Thus, although both organizations have centred a large part of their activities around women's 'practical gender interests' they have done so in a critically different manner. From one point of view those observers who point out the continuity of the activities of both organizations are right. However, the PKK's involvement never constitutes a threat to the prevailing order; it even strengthens women's subordination. While Gerwani can be said to have threatened the existing social order and gender subordination. Although it may be true that it did not always attack the existing sex-gender system in as systematic and consistent a way as our present-day feminist theories may dictate, it is also true that its attacks were none the less so stinging that conservative, patriarchal forces were highly antagonized. As such it addressed issues that most present-day feminists would call 'strategic'. We might even come to the conclusion that the viciousness of the attacks against Gerwani and the extent of the murders not only point to the failure of the organization to bring about meaningful change, but also should be seen as the sad proof of the ineffectiveness of their rebellion against the forces oppressing women. 


\section{Notes}

Saskia Wieringa is a lecturer in the Women and Development Programme at the Institute of Social Studies in The Hague, Holland. She did fieldwork in Indonesia, India and Peru, made a documentary film on batik labourers, wrote a novel and published widely on issues of women and organization. She is currently editing a book on Women's Movements in Historical Perspective.

Abbreviations used in this article:

AK-Api Kartini

Gerwani - Gerakan Wanita Indonesia

Golkar - Golongan Karya.

HR - Harian Rakyat

Nasakom - Nasionalis, Agama, Komunis

PKK - Pembinaan Kesejahteraan Keluarga

PKI - Partai Komunis Indonesia

Perwari - Persatuan Wanita Republik Indonesia

1 An extended version of this article will appear in: Stretching Boundaries: Women's Movements and Organizations in Historical Perspective, ed. S. Wieringa, forthcoming.

2 Indonesia has the largest Islamic population of the world. Generally they are divided into two groups, the santri who we might nowadays call the fundamentalists, and the abangan, the majority of the Islamic population, who mix their Islamic faith with many elements from the traditional Indonesian religions and/or with Hinduism. When I here refer to the Muslim groups, I refer to political organizations mainly made up of santris. The other two political actors addressed in this article, the PKI and the army, also contain many Muslims, but they are mostly abangan.

3 Since 1959 Indonesia claimed sovereignty over Irian Jaya, the last remaining part of the archipelago under Dutch control. In December 1961 the conflict turned into an armed confrontation. On 1 May 1963 Irian Jaya was placed under direct Indonesian rule, on condition that in 1969 a plebiscite would be held for the Papuan population. In September 1963 Indonesia embarked on a confrontation with the newly formed Federation of Malaysia. The formation of this new state was seen as a 'neo-colonial project designed by Great Britain'. These two military campaigns enhanced the army's prestige and helped ruin the country's economy.

4 Kartowiyono (1975) has analysed the implications of Sukarno's polygamy for the Indonesian women's movement in general and for Perwari, of which she was the chairperson in those years, in particular.

5 Langenberg (1986) has provided us with an interesting analysis of Indonesian government rhetoric.

6 Pancasila is the name of the official government philosophy. It is based on five principles which were originally formulated by Sukarno in 1945.

7 Gerwani members were said to have engaged themselves in 'obscene dancing', of 'mutilating the generals' genitals and of gouging out their eyes' on the field where the rebellious soldiers killed some generals. Subsequent reports indicated that Aidit (the chairman of the PKI) had had hundreds of Gerwani women trained to become prostitutes for the service of himself and other male party leaders. In cartoons which appeared for instance in the army newspaper, the PKI was pictured as a devil, with Gerwani written on its body. 


\section{References}

ANDERSON, Ben (1987) 'How Did the Generals Die?' Indonesia no. 43, Ithaca: Cornell Southeast Asia Program.

CROUCH, Harold (1978) The Army and Politics in Indonesia Ithaca: Cornell University Press.

FEITH, Herbert (1962) The Decline of Constitutional Democracy in Indonesia Ithaca: Cornell University Press.

GUNAWAN, B. (1968) Kudeta, staatsgreep in Djakarta, de achtergronden van de 30 september-beweging in Indonesie Meppel: Boom.

KARTOWIYONO, Sujatin (1975) Perkembangan pergerakan wanita Indonesia Jakarta: Yayasan Idayu.

LANGENBERG, Michael Van (1986) 'Analysing Indonesia's New Order State: A Keywords Approach?' RIMA, Review of Indonesian and Malaysian Affairs Summer.

MAY, Brian (1978) The Indonesian Tragedy Singapore: Graham Brash.

MOENADI, Mrs (1971) Family Welfare Education Jakarta: Pendidikan Kesedjahteraan Keluarga (PKK).

MOLYNEUX, Maxine (1985) 'Mobilization Without Emancipation? Women's Interests, State and Revolution in Nicaragua' in SLATER (1985).

MORTIMER, Rex (1974) Indonesian Communism Under Sukarno. Ideology and Politics 1959-65 Ithaca: Cornell University Press.

ROESTAM, Mrs Kardinah Soepardjo (1988) Family Welfare Movement (PKK) in Indonesia and its Achievement Jakarta: PKK.

RICKLEFS, M. C. (1981) A History of Modern Indonesia, c 1300 to the present London: Macmillan.

SARDJONO, Umi (1964) Madju Terus untuk Pengintegrasian total Gerwani dengan Wanita Buruhtani dan Tanimiskin Laporan kepada Sidang Pleno ke-III DPP Gerwani, Djkarta: DPP Gerwani.

SLATER, D (1985) New Social Movements and the State in Latin America, Amsterdam: CEDLA.

SUKARNO, Ir (1963) Sarinah, Kewadjiban Waniua dalam Perdjoangan Republik Indonesia Jakarta. Panitya penerbit buku-buku presiden Sukarno (Committee to publish the works of President Sukarno).

TÖRNQUIST, Olle (1984) Dilemmas of Third World Communism: the destruction of the PKI in Indonesia London: Zed Books.

WERTHEIM, W. F. (1978) Van Vorstenrijk tot Neo-Kolonie Amsterdam: Van Gennep.

- (1985) Wiens Samenzwering? Nieuw Licht op de Gebeurtenissen van 1965 in Indonesië: de Waarheid omtrent 1965, Amsterdam: 'Indonesia Media'.

WIERINGA, Saskia (1981) 'En Overal laat zij Bloedsporen achter; Macht, sekse en Klasse in de Batikindustrie van Midden Java' SocFem Teksten 5 Amsterdam: Sara.

(1985) The Perfumed Nightmare, some Notes on the Indonesian Women's Movement The Hague: ISS.

- (1988a) 'Aborted Feminism in Indonesia, a History of Indonesian Socialist Feminism', in WIERINGA (1985).

— (1988b) editor, Women's Struggles and Strategies London: Gower Press. 